\title{
Selected Aspects of Biofuels Market and the Electromobility Development in Poland: Current Trends and Forecasting Changes
}

\author{
Adam Kupczyk ${ }^{1}$, Joanna Mączyńska ${ }^{1}$, Grzegorz Redlarski ${ }^{2, *}$ (), Karol Tucki ${ }^{1}{ }^{1}$, Anna Bączyk ${ }^{3}$ \\ and Dominik Rutkowski ${ }^{1}$ \\ 1 Faculty of Production Engineering, Warsaw University of Life Sciences, 164 Nowoursynowska Str., \\ 02-787 Warsaw, Poland; adam_kupczyk@sggw.pl (A.K.); joanna_maczynska@sggw.pl (J.M.); \\ karol_tucki@sggw.pl (K.T.); dominik_rutkowski@sggw.pl (D.R.) \\ 2 Faculty of Electrical and Control Engineering, Gdańsk University of Technology, 11/12 Narutowicza Str., \\ 80-233 Gdańsk, Poland \\ 3 Department of Hydraulic Engineering, Warsaw University of Life Sciences, 159 Nowoursynowska Str., \\ 02-776 Warsaw, Poland; a.baczyk@levis.sggw.pl \\ * Correspondence: grzegorz.redlarski@pg.edu.pl; Tel.: +48-58-347-23-17
}

Received: 14 November 2018; Accepted: 7 January 2019; Published: 11 January 2019

\begin{abstract}
This work presents basic information associated with markets of selected alternative fuels used in transport, such as methyl esters, conventional bioethanol and lignocellulosic bioethanol, and the market of electrical vehicles. Legal conditions, which stimulate development and regulate the mode of functioning of the liquid biofuel market until 2020 are discussed, based on provisions of EU directives. Data on biofuel production in Poland are presented, as well as biofuel consumption in the EU, the USA and Brazil in 2017. The most important conclusions of the proposal for a directive on the promotion of renewable energy sources in transport in EU member states in years 2021-2030 are discussed. The authors have also indicated the key legal and territorial conditions associated with the development of electromobility and present basic information on electric vehicles in Poland and Europe. The results of the research on the attractiveness of these sectors in 2018 are presented and compared with the results obtained in years 2007-2017. A score-based sector attractiveness method was used in the research.
\end{abstract}

Keywords: transport; liquid biofuels; biocomponents; electrical drive; electromobility

\section{Introduction}

The transport sector of the European Union (EU) is responsible for approximately $1 / 3$ of the total demand for energy, which is mostly satisfied with petroleum derivative fuels [1]. This situation results in a substantial dependency of the sector on the import of petroleum and makes it a significant factor generating pollution of the natural environment [2]. Solutions aimed at limiting these problems include the use of renewable fuels, such as liquid biofuels, in vehicles equipped with diesel engines [3] as well as increasing the share of alternative means of transportation-electrical vehicles [4]. The state of interest in the topic of biofuels and electromobility can be seen in recent scientific literature (Figure 1), which depicts a steady increase in the interest in both areas. Biofuel production and usage is also the topic of several works related to planning and other optimization problems. 


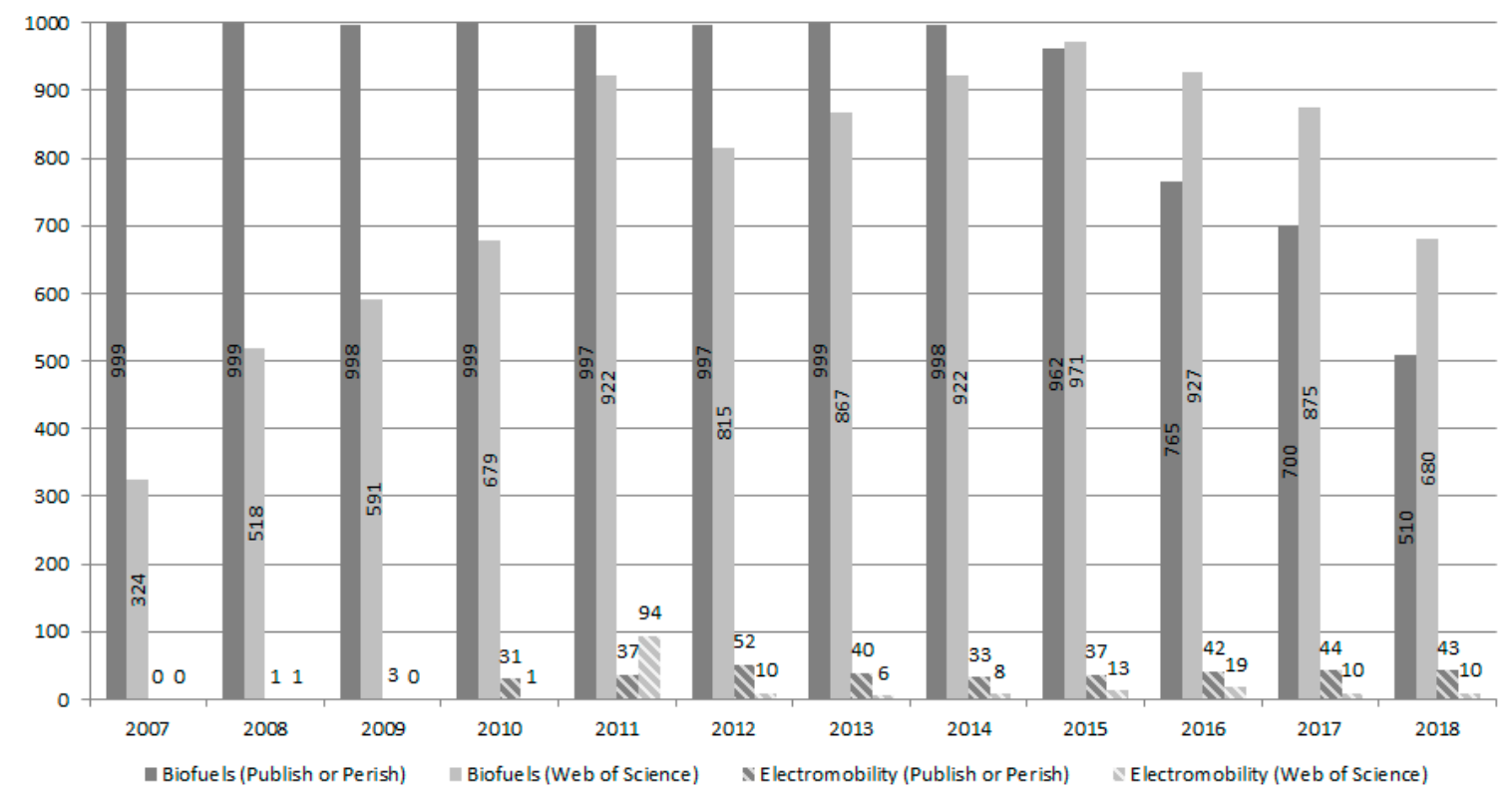

Figure 1. Scientific publications about biofuels and electromobility in the past decade.

Liquid biofuels constitute a fuel category, which includes substances made of raw materials of organic origin-biomass or biodegradable fractions of waste [5]. These include bioethanol, ester, pure vegetable oil, liquid bio-hydrocarbons and bio-propane-butane [6]. The substances listed may be used as fuels or as biocomponents, that is, additions to petroleum derivatives used as fuels in the existing transport infrastructure (gasoline and diesel oil) [7]. However, in accordance with EU policies, vehicles with electrical drives will become one of the key means of transport in urban agglomerations in the future. Therefore, the issue of electromobility [8] is increasingly important. It is a vast term, encompassing all issues associated with electrically driven vehicles, that is, the vehicles themselves, charging infrastructure, as well as social, economic and legal aspects of their production, sale, use and disposal. According to provisions of the Act on electromobility and alternative fuels (Journal of Laws of 2018 item 317), an electric vehicle is "a motor vehicle... driven only by electrical energy accumulated by connecting to an external source of supply." Worth noting is also the definition of a hybrid vehicle, that is: "a motor vehicle... with a diesel-electric propulsion system, in which electrical energy is accumulated by connection to an external source of supply" [9]. It means that, for instance, "a hybrid Toyota", according to the provisions of the act, is not a hybrid vehicle, as it cannot be charged with an "external source of supply" (as of 25 April 2018, the only exception is Prius Plug-in [10]). Electromobility, which has been so strongly promoted lately, is not a new solution. According to the definition quoted above, trolleybuses, forgotten in Poland, fit into the concept of electrical vehicles. Although, thanks to firms like Ursus and Solaris, Poland is a potentate in their production in Europe, they are used only in Lublin, Gdynia and Tychy, but most vehicles are produced for export [11].

\section{The Market of Biocomponents and Liquid Biofuels}

\subsection{Basic Legal Regulations}

The basic legal act regulating the market of biocomponents and liquid biofuels in Poland is the systematically amended Act of 25 August 2006 on biocomponents and liquid biofuels (Journal of Laws of 2006 no 169 item 1199 as amended) [12]. It is a result of the obligation to implement provisions of the EU directives on the use of renewable energy in transport. The first version of the act, published in 2006, implemented provisions of Directive 2003/30/EC on the promotion of the use of biofuels or other renewable fuels for transport (OJ L 123 of 17.5.2003) [13]. Subsequent versions of the document gradually implemented provisions of Directive 2009/28/EC on the promotion of the use of the energy 
from renewable sources and amending and subsequently repealing Directive 2003/30/EC (OJ L 123 of 17.5.2003) [14] and its amending Directive 2015/1513/EC (OJ L 2015.293.1) [15].

On the basis of the EU legislation, the member states are obligated to ensure at least a 10 percent share of renewable energy in the final consumption of energy in transport until the year 2020. In order to fulfil this obligation from produced biofuel, and to be eligible for assistance from public support systems, it must meet the Sustainable Criteria (SC). These were introduced to limit the potential negative effects associated with intensified production of biofuels, stimulated by the obligation to use them. The SC determine the minimum level of reduction of greenhouse gas emission, which must be achieved thanks to the use of biofuels (in relation to the emission from fossil fuels) and indicate that the raw materials used for their production must not come from areas characterized by high biodiversity [16].

The sectoral objective for year 2020 was established by Directive 2009/28/EC, and then Directive 2015/1513/EC provided details on the means of its achievement. It was noticed that increasing demand for biofuels, resulting from efforts made to achieve the established objective, may lead to transformation of cropland used to grow food and fodder into land used for growth of raw materials to be used for biofuel production. As a result, the demand reported by the market of raw food materials must be satisfied through the intensification of current production or the transformation of land not used to grow crops into arable land. The second variant, known as an intermediate change of land use, if associated with the transformation of coal-rich areas, may result in a substantial emission of greenhouse gases, which will cancel out the Greenhouse Gas (GHG) reduction attributed to biofuels. As a result of identifying this phenomenon, the classification of biofuels was introduced, and it was decided that the share of energy from conventional biofuels (produced from cereals and other edible plants) may constitute no more than $7 \%$ of the final consumption of energy in transport in 2020 . The remaining $3 \%$ can be attained by the member states thanks to electrical mobility or by using advanced biofuels, which are made of raw non-food materials, listed in appendix IX to Directive 2015/1513/EC (including algae, straw, manure and sewage sludge) [17].

\subsection{Production of Biocomponents in Poland}

Business activity in the field of production of biocomponents and liquid biofuels, as defined by provisions of the Act of 6 March 2018-Entrepreneurship Law Act (Journal of Laws of 2018 item 1633) [18], is a regulated activity, which requires entry in the register of manufacturers, maintained by the Director General of the National Centre for Support of Agriculture. As of 10.10.2018, there were 24 entrepreneurs entered in the register, holding a total of 27 installations for the production of biocomponents. In this number, 15 of these were used for production of bioethanol (of the declared capacity of 909.5 million litres/year), 9 are installations for production of fatty acid methyl esters (1520.7 million litres/year), 2 facilities for production of liquid bio-hydrocarbons (32.5 million litres/year) and 1 for the production of bio propane-butane (3.5 million litres/year) [19]. Due to the great number and annual performance of the installations for production of methyl esters and bioethanol, further analysis will be focused on these biocomponents.

In accordance with the recommendations of the National Centre for Support of Agriculture (KOWR), on when it is necessary to change the volume units to mass units with regards to data on the biocomponents, it is necessary to apply a density of $892 \mathrm{~kg} / \mathrm{m}^{3}$ for methyl ester and $778 \mathrm{~kg} / \mathrm{m}^{3}$ for bioethanol [20]. In association with the above, upon transforming the annual performance of the installations used for production of these biocomponents in 2018, expressed in the register of entrepreneurs in million litres per year, the values of 1356.6 thousand tons for esters and 707.6 thousand tons for bioethanol were obtained, respectively.

In the 1st and 2nd quarter of 2018, 406.7 thousand tons of methyl esters were produced, including 4.4 thousand tons of biocomponents meeting the SC, which were eligible to count as double values in the achievement of the sectoral objective. At the same time, 103.3 thousand tons of bioethanol were produced, including 1.1 thousand tons eligible to count as double values. For the production 
of esters, 408.3 thousand tons of raw material were used, in which $98.7 \%$ was rapeseed oil, and for the production of bioethanol, 422.5 thousand tons of substrate were used, $53.5 \%$ of which was corn. The raw materials, which allowed for the counting of biocomponents as double values for achievement of the target established for 2020, were rapeseed oil $(0.7 \%)$, as well as animal fats of category $2(0.4 \%)$ in the case of methyl esters, and food waste (1.0\%) in the case of bioethanol [21].

In the analysis of the Polish market of biocomponents, of significance is the actual degree of utilization of the declared production capacity by manufacturers of methyl esters and bioethanol. In 2017, manufacturers of these biocomponents registered installations for the total annual capacity of 1356.5 thousand tons of esters and 667.9 thousand tons of bioethanol [22], while the actual production was 897.0 thousand tons of esters and 203.7 thousand tons of bioethanol [23]. This means that the annual production capacity of Polish manufacturers of biocomponents were used at $66.1 \%$ in the case of methyl esters and at 30.5\% in relation to bioethanol. In the period from 2013 until 2017, the average degree of utilization of production capacity amounted to $67.4 \%$ for esters and $29.0 \%$ for bioethanol [24,25].

\subsection{Biofuels in the European Union, the USA and Brazil}

According to estimates of EurObserv'ER published in the report "Biofuels Barometer", the total consumption of liquid biofuels in the European Union in 2017 amounted to 15514.6 kilotons of equivalent oil (ktoe). The highest share in this group was assigned to fatty acid esters, so-called biodiesel (including synthetic biodiesel, the so-called HVO biodiesel, resulting from the process of hydrogenation, developed and patented by the Finnish oil company, Neste Oil. This technology has been implemented on an industrial scale in 6 European countries). Biodiesel accounted for $80.7 \%$ of total consumption and bioethanol for $18.4 \%$ [26]. According to estimates, $99.7 \%$ of biofuels used in transport in the EU in 2017 met the SC defined in Directive 2009/28/EC. The highest consumption of biofuels was estimated to take place in France-3335.0 ktoe (21.5\%), Germany-2608.2 ktoe (16.8\%) and Sweden-1646.4 ktoe (10.6\%). Consumption in Poland was estimated to amount to $581.1 \mathrm{ktoe}$ $(3.7 \%)$, which placed the country in the 8 th position in relation to the remaining member states [27].

On a global scale, most biofuels are manufactured and consumed in the United States and Brazil. In 2017, consumption of biofuels in the USA was more than double that of the EU, amounting to 38803.3 ktoe. Consumption of biofuels in Brazilian transport was also higher than in the entire EU and amounted to 16320.4 ktoe [28]. Unlike on the European market, on the global scale, the biofuels produced in the biggest quantities are bioethanol [29]. In 2017, bioethanol consumption in the United States, where it was produced locally mainly from corn, amounting to $28933.1 \mathrm{ktoe}$, and in Brazil, where sugar cane is the main raw material-to $12912.1 \mathrm{ktoe}$ [30].

The Renewable Fuel Standard was approved in 2005 and extended two years later, the RFS initiated a period of dynamic development in the sector of biofuels in the USA. It is considered to be one of the most effective biofuel policies in the United States, which has contributed substantially to the reduction of petroleum imports and air pollution. At present, there are 211 ethanol biorefineries in the USA, located in 28 states [31]. They produce ethanol, which is used mostly in two variants of mixtures with petrol-as E10 (10\% of ethanol volume) and E15 (15\% of ethanol volume) [32]. Moreover, the market offers so-called flex fuels, which are mixtures of petrol and ethanol in the amount of $51 \%$ to $83 \%$ of ethanol. In 2017, the number of retail gasoline stations selling such fuels crossed the threshold of 4 thousand. Flex type fuels are to be used exclusively in vehicles equipped with a flex-fuel propulsion system. In 2017, the number of vehicles supplied in this manner in the American car fleet amounted to 24 million cars, meaning that one out of ten cars traveling along American roads was equipped with this technology [33].

Brazil is one of the biggest global bioethanol producers and one of the pioneers of its use as a motor fuel. Moreover, this country is a very good example of legislative support for bioethanol production. In 1975, when the petrol crisis led to a substantial increase in the costs of the import of petroleum, the Brazilian government launched a domestic program to support the development of the 
bioethanol market, the so-called ProAlcool [34]. The program encouraged the production of ethanol from sugar cane and established a law that required blending petrol with ethanol at the ratio of 80:20. At present, according to Brazilian law, petrol should contain $25 \%$ of bioethanol [35]. The development of the bioethanol market in Brazil has also been substantially influenced by the introduction, in 2003, of cars equipped with engines with flex-fuel technology. This solution allowed the consumers to select between ethanol and petrol, depending on the fluctuations in market prices. In reality, nine out of ten vehicles sold in Brazil nowadays are equipped with this technology [36].

\subsection{Biofuels in the European Union in Years 2021-2030}

Directive 2015/1513/EC, amending Directive 2009/28/EC, establishes a framework for the use of renewable energy in transport in the perspective for 2020. In 2016, the European Commission, in proposal no. 2016/0382(COD) [37] suggested updating the Directive on renewable sources of energy, which sets the path for the popularization of biofuels in the EU for the years 2021-2030. From the moment of its first publication, the document was subject to modifications [38], and its final text was agreed by the EU institutions in June of 2018 [39]. The original proposal of the Commission did not encompass the sectoral objective associated with renewable energy in transport. However, according to the final version of this document, the member states will be obliged to make sure that the share of renewable energy is at least at $14.0 \%$ of the final consumption of energy in road and railway transport in 2030 [40]. Within the framework of supporting the process of switching to advanced biofuels, a binding sub-objective has been established, which increases the share of manufacturing biofuels from non-food raw materials, included in part A of appendix IX of the proposal, so that in the year 2022 this share is at least $0.2 \%$, in 2025-at least $1.0 \%$, and until the year 2030 it is to increase to at least $3.5 \%$. Such raw materials include: Algae, sewage sludge, raw glycerine, straw and other non-food cellulosic and lignocellulosic materials. Advanced biofuels made of such raw materials will be eligible to count as a double value for the purpose of achievement of the sub-objective (3.5\%) and the sectoral objective (14.0\%). In addition, part B of appendix IX lists other non-food raw materials, which are also counted at their double value, such as used cooking oil and animal fats of category 1 and 2 . However, their share is limited to $1.7 \%$ in the perspective until year 2030 [41].

\section{Electromobility}

\subsection{Legal Conditions of Electromobility}

A significant aspect of implementing electric vehicles are legal provisions. At present, the European Union is very much interested in the problems associated with the reduction of carbon dioxide $\left(\mathrm{CO}_{2}\right)$ emissions. Two EU documents, that is, the Roadmap for moving to a competitive low-carbon economy in 2050 [42] and the Roadmap to a single European transport area-Towards a competitive and resource efficient transport system [43], provide for a reduction of carbon dioxide $\left(\mathrm{CO}_{2}\right)$ emissions by $60 \%$ in relation to the year 1990. In this situation, it is important to define not only the legal, but also the systemic short-term solutions that would support market competitiveness. Also worth noting is the Directive 2008/50/EC of the European Parliament and of the Council of 21 May 2008 on ambient air quality and cleaner air for Europe [44]. At present, the European Union has legal provisions and standards that regulate the level of emissions of harmful substances, such as: Carbon dioxide, nitrogen oxides, sulphur dioxide, ammonia or volatile organic compounds. Poland has developed the Strategy for responsible development until the year 2020 (with a perspective until 2030) [45], which includes two projects on electromobility. The first one is the e-bus, concerning the stimulation of designing and producing electric buses, while the second one-the electric car-provides assistance in boosting the development of technology, production and the market of electric cars. According to the Strategy, conditions are to be established until 2020 to facilitate the placement of vehicle charging stations and enabling the purchase of electric buses for the purpose of development of low-emission collective transport. The Ministry of Energy estimates that the planned million electric vehicles in the country 
will consume 4.3 TWh of electricity per year [46]. It is also worth noting here that in 2017, Poland purchased 2.3 TWh, which constitutes more than a half of the planned consumption of electricity by cars [47].

\subsection{Territorial Conditions}

It is important to mention that the development of electromobility is often influenced by the urbanization of a given country, which often passes unnoticed. For instance, in the Netherlands, there are about 16.5 million inhabitants in an area of little more than 41 thousand $\mathrm{km}^{2}$. Thus, the urbanization index in the country is around 503 inhabitants $/ \mathrm{km}^{2}$ [48], which makes it a good place for the implementation of electric cars. However, in Poland, it is about 121 inhabitants $/ \mathrm{km}^{2}$ [49], which indicates a much greater distance between urban centres. In addition, about $96 \%$ of the Dutch live in cities, while in Poland it is around 61\% [50].

\subsection{Electric Vehicles in Poland and Europe}

On the Polish market, there are fully electrical vehicles of such brands as Smart, Renault, Hyundai, Nissan and the most popular BMW (i3) [51]. According to the Innogy Polska report: highway to electromobility, for $41 \%$ of private persons and $73 \%$ of entrepreneurs, the most significant barrier hindering the development of electric vehicles is the lack of a publicly available network of fast charging stations. For $50 \%$ of entrepreneurs, the second most significant limitation is the range of these vehicles [31]. The availability of fast charging stations makes it possible to move comfortably around big cities. Covering the routes between the cities, using expressways or highways, which, due to lack of braking, fail to ensure sufficient energy recovery, which constitutes a great challenge and makes the travel time much longer in comparison with cars with diesel engines. The charging time of an average vehicle under household conditions, at the standard charging parameters $(2.2 \mathrm{~kW})$ with batteries of capacity of $30 \mathrm{kWh}$ is $16 \mathrm{~h}$. The situation is slightly better when it comes to public charging points $(3.3 \mathrm{~kW})$, where this time is reduced to $9-10 \mathrm{~h}$. The problem is solved by fast chargers $(62.5 \mathrm{~kW})$, as a full charge takes about $30 \mathrm{~min}$. However, these are scarce in Poland. In addition, it is necessary to consider charging losses at a level of 5-10\% [52]. Another problem associated with batteries is their capacity. This problem will be less burdensome for owners of new cars; however, assuming the limit value of $3.4 \%$ for the loss of battery capacity per 10 thousand kilometres, let us assume for the purpose of our calculations a value of 3\%. Traveling 30 thousand kilometres per year, we lose $9 \%$ of the capacity each year, and after 5 years it may turn out we have left only $55 \%$ of the range that we were able to achieve on the date of purchase. A lot depends on the climate; however, the climate of Poland is not favourable for such cars due to a high amplitude of temperatures. The systems which recover energy during braking are able to travel at a longer distance, but over time, out of the original $378 \mathrm{~km} \mathrm{[53]}$ declared by the manufacturer, one would be able to travel less than $210 \mathrm{~km}$. Let us keep in mind that this is the manufacturer's data-that is, a very optimistic variant. According to data from Tom Tom [54] on road traffic in Europe, 7 of Polish cities occupy places among the top 35, and it is known that in heavy traffic, the demand for energy increases substantially.

Another significant problem in Poland is the origin of electricity. In countries, in which energy comes largely from renewable sources (RES), such as water, wind or sun, the discussed cars are indeed more environment-friendly on the local scale in comparison with cars with internal combustion engines, such as diesel engines. Although the technology is now developing, and progress in this regard has made us believe that these cars may become more environment-friendly than they are now, charging requires electricity, which in Poland comes mainly from coal-fired plants.

Another serious problem in the future will be the disposal of used-up batteries and the content of numerous rare earth minerals in electric vehicles.

The sale of fully electrical cars (BEV-Battery Electric Vehicles) in the eastern part of Europe is much lower in comparison with the West, although such countries as the Czech Republic, Romania and Lithuania do not make a difference between the sales of hybrid vehicles, a so-called Plug-in 
(PHEV-Plug-in Hybrid Electric Vehicles) and that of BEV vehicles. This is due to specific territorial and legal characteristics, as well as the level of affluence of the society. In 2017, most of such cars were sold in Germany (more than 25,056 units), France (24,910 units) and Great Britain (13,597 units). The highest unit increase in sales in comparison with year 2016 was recorded in Germany (13,646 units) and the Netherlands (5629 units). The same states also recorded the highest increase in the number of vehicles powered by alternative energy sources (AFV-Alternative fuel vehicle), that is, electric cars, hybrids and cars using alternative supply sources (other than electricity). The percentage increase in sales of BEV cars in such countries as Greece (216.7\%), Poland (306.0\%), Hungary (335.5\%) and the record-breaking Bulgaria (1260\%) is undoubtedly amazing. Nevertheless, as we compare this to the increase in the number of vehicles on the roads in these countries, we obtain the following results: 26 , $331,577,63$ units. [55].

Worth noting is that the sale of electrical cars in individual months. In March 2018, 4970 BEV cars were registered in France [56] and 3792 cars in Germany [57]. Nevertheless, the real record-holder is Norway, where 5362 such cars were registered in the same time period. Thus, their market share grew to $37.2 \%[58]$.

\section{Comparison of Attractiveness of the Biofuel and Electric Car Markets}

A score-based assessment of sector values was used to compare the attractiveness of the selected sectors. The scope of analysis included methyl esters of rapeseed oil, conventional and lignocellulosic bioethanol, as well as electric cars, which were analysed from the perspective of the year 2018 . The method used is based on the assessment of intensity of factors that differentiate individual sectors, as well as their attractiveness. The assessment was performed by persons having extensive knowledge on the sectors being analysed (experts) using the same evaluation grid containing the selected criteria. The test was performed using 15 factors, assessed on a scale of 0 to 3 according to the plan illustrated in Table 1. On the basis of the obtained scores, the average attractiveness values were assigned to individual sectors, expressed in percentage values, assuming that $0 \%$ is equivalent to an unattractive sector and $100 \%$ - to a very attractive sector [59-62].

The attractiveness of the sector of conventional biofuels, that is, methyl esters and bioethanol, has been analysed by many authors starting from 2007, and the results have been published in many articles [63-66]. Since 2013, the sector of lignocellulosic bioethanol was also assessed. In 2018, the scope of research was extended to include the sector of electric cars, and the results obtained were compared to those for the previous years in Figure 2.

Table 1. Sector attractiveness evaluation grid used in the research.

\begin{tabular}{|c|c|c|c|}
\hline \multirow{2}{*}{ Criterion } & \multicolumn{3}{|c|}{ Scale of Values } \\
\hline & 0.5 & $1.5 \quad 2$ & 2.5 \\
\hline Sector Size & Small & Medium & Large \\
\hline The expected growth rate for the sector & $<2 \%$ & $2-8 \%$ & $\leq 8 \%$ \\
\hline Intensity of competition & High & Average & Low \\
\hline Sector concentration level & Monopoly & Oligopoly & Dispersed \\
\hline Entrance barriers & Weak & Medium & Strong \\
\hline Substitution risk & High & Medium & Low \\
\hline Availability of resources & Low & Average & High \\
\hline Price level & Price war & High flexibility & High margin of freedom \\
\hline Profit margin & Low & Average & High \\
\hline Seasonality of sales & High & Average & Low \\
\hline Source of added value & Typical & Know-how & Exceptional advantages \\
\hline Innovation potential & Low & Medium & High \\
\hline Activity diversification capacity & Low & Average & High \\
\hline Favoured by UE policy & Low & Average & High \\
\hline Social perception of the sector & Unfavourable & Medium & Favourable \\
\hline \multicolumn{4}{|c|}{ Total } \\
\hline
\end{tabular}

Source: Own compilation based on [67]. 


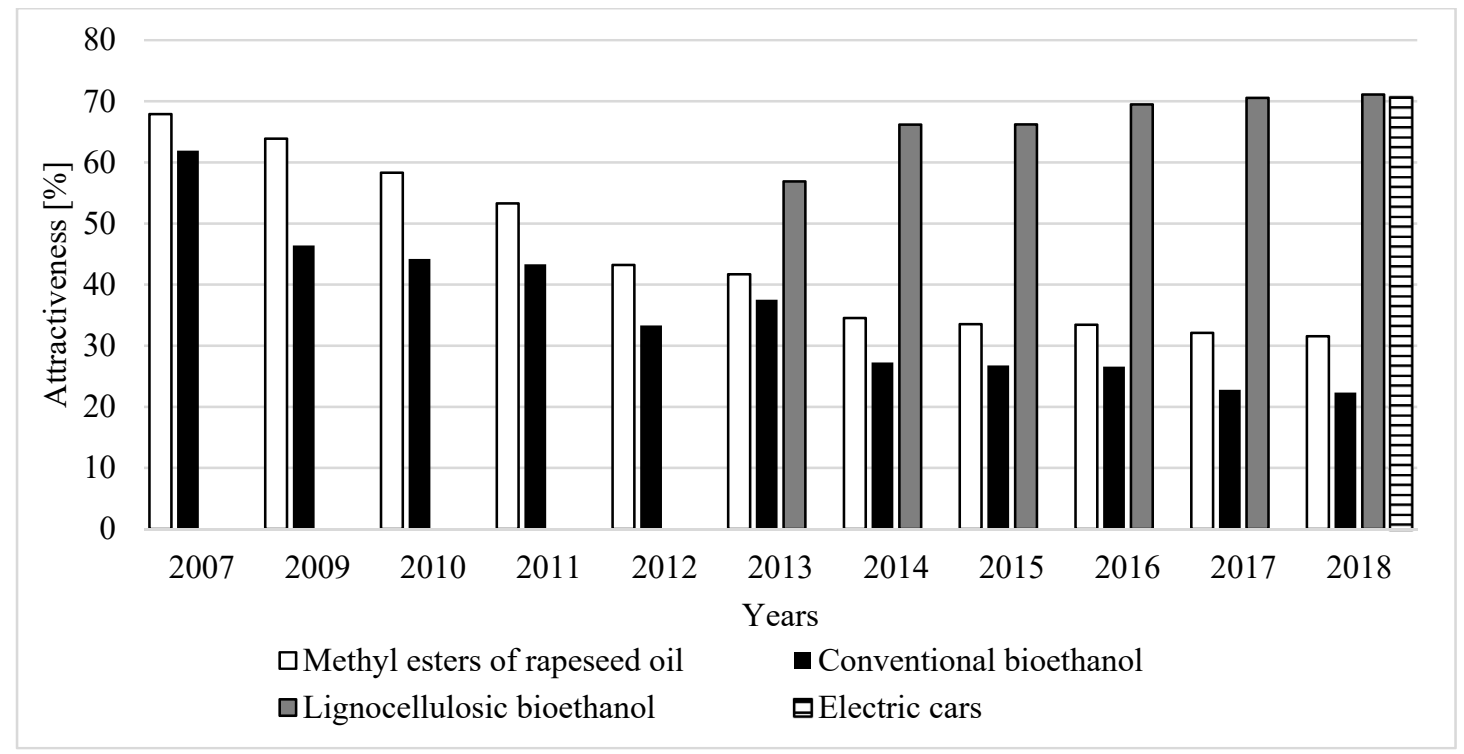

Figure 2. Attractiveness of selected sectors in Poland in years 2007-2018 (\%). Source: Own research for years 2007-2018.

At the beginning of the analysed period (2007), the results obtained for biofuels made of raw food materials were very promising. At the time, the sectors of methyl esters and conventional bioethanol were assessed as relatively attractive components of the economy ( $67.9 \%$ and $61.9 \%$ respectively). In the subsequent years, the level of attractiveness of these sectors kept decreasing. In the research conducted in the year 2018, 31.56\% was obtained for rapeseed oil methyl esters (standard deviation: 3.82), 22.33\% for conventional bioethanol (standard deviation: 4.51), 71.11\% for lignocellulosic bioethanol (standard deviation: 3.51 ) and $70.56 \%$ for electric cars (standard deviation: 8.65 ). The current results of the value assessment of sectors of biofuels do not encourage investing in the production of methyl esters and conventional bioethanol. On the other hand, they indicate that from the perspective of research project participants, advanced bioethanol is the most attractive product. However, the production of biofuel from lignocellulosic biomass, due to high resistance to biochemical digestion of the raw materials used, remains an expensive way of obtaining bioenergy. At present, there are no facilities in Poland that could produce this biofuel at an industrial scale. During the last decade, many research centres around the world have conducted numerous research projects on the effective recovery of fermenting sugars from lignocellulosic biomass and the reduction of total production costs [68-72]. Nevertheless, the process has remained a substantial challenge [73]. At present, the value of the sector of electric fuel for motorization purposes (an emerging sector) is high at a level of more than $70 \%$, just like in 2007 for the then emerging sector of conventional biofuels.

\section{Summary}

At present, an intensified increase in the significance of alternative solutions for transport can be observed [74,75]. For many years, great emphasis has been put on biocomponents and liquid biofuels used in vehicles equipped with internal combustion engines [75,76]. However, an established limit for conventional biofuels and problems encountered in effective production of advanced biofuels, have led to an increased focus on electric propulsion vehicles [77-81].

Domestic policies of individual member states promoting renewable energy in the transport sector focus mainly on road transport and the use of biofuels and electric mobility [76]. In Poland, the production of biofuels for many years has been based on raw materials of agricultural origin, such as rapeseed oil and corn [77-79]. The trend consisting of basing the market of biofuels on raw food materials has been observed also in the European Union, the USA and Brazil [82-87]. However, as it has been pointed out by the European Parliament, it is necessary to increase the pace 
of development of biofuels from raw non-food materials and popularize electromobility in road transport [81]. In association with the above, the popularity of electric propulsion vehicles has been growing, both in the sector of fully electrical, and combined electrical and diesel vehicles [88-94]. Nevertheless, the development of electromobility requires further investment, as well as additional legal and economic solutions to establish favourable conditions to encourage consumers to purchase and use such vehicles [95-97]. Moreover, there are reasonable doubts in regard to the real limiting of emissions thanks to electrically-charged vehicles [98]. The reduction of $\mathrm{CO}_{2}$ emissions by a specific fuel is its basic feature, perceived either as advantageous or disadvantageous. Electric propulsion has a visible advantage over liquid fuels, its emission level is close to zero (almost zero emission of greenhouse gases) when electrical energy is used by the electric engine [99-101]. On the other hand, it is a disadvantage that electricity used for electromobility is still produced mainly using fossil fuels. When it comes to doubts associated with the real reduction of emissions thanks to the use of electric vehicles, it is also necessary to solve problems associated with the disposal of batteries used in vehicles of this kind [102].

Author Contributions: Conceptualization, G.R. and A.K.; methodology, G.R. and J.M.; data curation, K.T. and A.B.; Writing-J.M., K.T. and R.D.; Writing-Review and Editing, J.M., K.T. and R.D.; visualization, J.M. and K.T.; supervision, G.R. and A.K.; project administration, K.T.; funding acquisition, A.K.

Funding: This research received no external funding.

Conflicts of Interest: The authors declare no conflict of interest.

\section{References}

1. Proposal No 2016/0382 (COD) Pertaining to the Directive on Promotion of Use of Energy from Renewable Sources; European Commission: Brussels, Belgium, 30 November 2016.

2. Hosseinzadeh-Bandbafha, H.; Tabatabaei, M.; Aghbashlo, M.; Khanali, M.; Demirbas, A. A comprehensive review on the environmental impacts of diesel/biodiesel additives. Energy Convers. Manag. 2018, 174, 579-614. [CrossRef]

3. Redlarski, G.; Piechocki, J.; Dabkowski, M. Reducing Air Pollutant Emissions from the Residential Sector by Switching to Alternative Energy Sources in Single-Family Homes. Pol. J. Environ. Stud. 2013, 22, 197-203.

4. Prasad, T.V.; Prasannatha, B. Biomass-utilization and conversion. AIP Conf. Proc. 2018, 1992, 040017. [CrossRef]

5. Burdzik, P.; Folęga, P.; Konieczny, Ł.; Jaworsk, R. E-mobilność-wyzwanie teraźniejszości. Pr. Nauk. PW 2017, $118,17-29$.

6. Redlarski, G.; Krawczuk, M.; Kupczyk, A.; Piechocki, J.; Ambroziak, D.; Palkowski, A. Swarm-Assisted Investment Planning of a Bioethanol Plant. Pol. J. Environ. Stud. 2017, 26, 1203-1214. [CrossRef]

7. Central Statistical Office. Zasady Metodyczne Badań Statystycznych z Zakresu Energii ze Źródeł Odnawialnych; Central Statistical Office: Warsaw, Poland, 2016.

8. Act of 25 August 2006 on biocomponents and liquid biofuels. J. Laws Repub. Pol. 2006, 169, 1-11.

9. Smuga-Kogut, M.; Zgórska, K.; Kogut, T.; Kukiełka, K.; Wojdalski, J.; Kupczyk, A.; Dróżdż, B.; Wielewska, I. The use of ionic liquid pretreatment of rye straw for bioethanol production. Fuel 2017, 191, 266-274. [CrossRef]

10. Borkowska, H.; Molas, R.; Kupczyk, A. Virginia fanpetals (Sida hermaphrodita Rusby) cultivated on light soil; height of yield and biomass productivity. Pol. J. Environ. Stud. 2009, 18, 563-568.

11. Gradziuk, P. Możlizwości i Bariery Rozwoju Zaawansowanych Biopaliw w Polsce; Polski Klub Ekologiczny: Warsaw, Poland, 2017.

12. Londo, M.; Lensink, S.; Wakker, A.; Fischer, G.; Prieler, S.; Van Velthuizen, H.; De Wit, M.; Faaij, A.; Junginger, M.; Berndes, G.; et al. The REFUEL EU road map for biofuels in transport: Application of the project's tools to some short-term policy issues. Biomass Bioenergy 2010, 34, 244-250. [CrossRef]

13. Act of 11 January 2018 on electromobility and alternative fuels. J. Laws Repub. Pol. 2018, 317, 1-28.

14. Information on Available Car Models. Available online: www.toyota.pl (accessed on 15 April 2018). 
15. Sprzedaż Solarisa Najlepsza w Historii 70 Procent Idzie na Eksport. Available online: http://forsal. pl/artykuly/1102564,sprzedaz-solarisa-najlepsza-w-historii-70-proc-idzie-na-eksport.html (accessed on 15 April 2018).

16. Directive 2003/30/EC of the European Parliament and of the Council of 8 May 2003 on the Promotion of the Use of Biofuels or Other Renewable Fuels for Transport; OJ L 123 of 17.5.2003; EUR-Lex: Brussels, Belgium, 2003.

17. Directive 2009/28/EC of the European Parliament and of the Council of 23 April 2009 on the Promotion of the Use of Energy from Renewable Sources and Amending and Subsequently Repealing Directives 2001/77/EC and 2003/30/EC; OJ L 09.140.16; EUR-Lex: Brussels, Belgium, 2009.

18. Directive (EU) 2015/1513 of the European Parliament and of the Council of 9 September 2015 Amending Directive 98/70/EC Relating to the Quality of Petrol and Diesel Fuels and Amending Directive 2009/28/EC on the Promotion of the Use of Energy from Renewable Sources; OJ L 2015.293.1; EUR-Lex: Brussels, Belgium, 2015.

19. Act of 6 March 2018-Entrepreneurship Law Act. J. Laws Repub. Pol. 2018, 646, 1-19.

20. Register of Manufacturers State as of 10.10.2018. Available online: http:/ / www.kowr.gov.pl (accessed on 22 October 2018).

21. Information on Conversion of Biocomponents from Volume Units to Mass Units. Available online: http: / / www.kowr.gov.pl/interwencja/odnawialne-zrodla-energii/biokomponenty-i-biopaliwa (accessed on 22 October 2018).

22. Information on the Market of Biocomponents for the 1st and 2nd Quarter of Year 2018. Available online: http:/ /bip.kowr.gov.pl/informacje-publiczne/odnawialne-zrodla-energii/informacje-dotyczace-rynkubiokomponentow (accessed on 22 October 2018).

23. Biocomponents and Biofuels. Available online: http://www.kowr.gov.pl (accessed on 22 October 2018).

24. Information on the Market of Biocomponents. Available online: http://bip.kowr.gov.pl (accessed on 15 April 2018).

25. Kupczyk, A.; Mączyńska, J.; Sikora, M.; Gawron, J. Identyfikacja obecnego stanu oraz atrakcyjność sektorów biopaliw transportowych w Polsce. RN SERiA 2017, 19, 139-144. [CrossRef]

26. Mączyńska, J.; Klepacka, A.M. Wybrane aspekty związane z produkcją biokomponentów w Polsce oraz surowcami pochodzenia rolniczego wykorzystywanymi do ich wytwarzania. RN SERiA 2018, 20, 108-113. [CrossRef]

27. Brännström, H.; Kumar, H.; Alén, R. Current and Potential Biofuel Production from Plant Oils. BioEnergy Res. 2018, 11, 592-613. [CrossRef]

28. EurObserv'ER. Biofiuels Barometer; EurObserv'ER: Brussels, Belgium, 2018.

29. Raboni, M.; Viotti, P.; Capodaglio, A.G. A comprehensive analysis of the current and future role of biofuels for transport in the European Union (EU). AMBIAGUA 2015, 10. [CrossRef]

30. Eurostat. Renewable Energy Statistics. Available online: https://ec.europa.eu/eurostat (accessed on 10 January 2019).

31. Renewable Fuels Association. Ethanol Strong. In 2018 Ethanol Industry Outlook; Renewable Fuels Association: Washington, DC, USA, 2018.

32. Guo, M.; Song, W. The Growing U.S. Bioeconomy: Drivers, Development and Constraints. New Biotechnol. 2018. [CrossRef] [PubMed]

33. Kostin, A.; Macowski, D.H.; Pietrobelli, J.M.; Guillén-Gosálbez, G.; Jiménez, L.; Ravagnani, M.A. Optimization-based approach for maximizing profitability of bioethanol supply chain in Brazil. Comput. Chem. Eng. 2018, 115, 121-132. [CrossRef]

34. Paulino de Souza, J.; Dias do Prado, C.; Eleutherio, E.C.A.; Bonatto, D.; Malavazi, I.; Ferreira da Cunha, A. Improvement of Brazilian bioethanol production-Challenges and perspectives on the identification and genetic modification of new strains of Saccharomyces cerevisiae yeasts isolated during ethanol process. Fungal Biol. 2018, 122, 583-591. [CrossRef]

35. Barros, S. Biofuels Annual Brazil; USDA: Washington, DC, USA, 2017.

36. European Parliament. Amendments Approved by the European Parliament on 17 January 2018 on the Proposal Pertaining to Directive of the European Parliament and the Council on Promotion of Use of Energy from Renewable Sources (Amended Version); (COM(2016)0767-C8-0500/2016-2016/0382(COD)); European Parliament: Brussels, Belgium, 2018. 
37. Proposal for a Directive of the European Parliament and of the Council on the Promotion of the Use of Energy from Renewable Sources-Analysis of the Final Compromise Text with a View to Agreement 2016/0382 (COD); European Parliament: Brussels, Belgium, 21 June 2018.

38. International Council on Clean Transportation. Final Recast Renewable Energy Directive for 2021-2030 in the European Union. 2018. Available online: www.theicct.org/sites/default/files/publications/EU_Fuels_ Policy_Update_20180719.pdf (accessed on 27 October 2018).

39. Roadmap for Moving to a Competitive Low-Carbon Economy in 2050, (COM (2011) final version); European Commission: Brussels, Belgium, 2011.

40. Roadmap to a Single European Transport Area-Towards a Competitive and Resource Efficient Transport System, (COM (2011) 144 final version); European Commission: Brussels, Belgium, 2011.

41. Directive 2008/50/EC of the European Parliament and of the Council of 21 May 2008 on Ambient Air Quality and Cleaner Air for Europe; (OJ L. 08.152.1); European Commission: Brussels, Belgium, 2011.

42. The Council of Ministers. Strategy for Responsible Development until Year 2020; with a perspective until year 2030; The Council of Ministers: Brussels, Belgium, 2017.

43. Innogy. Innogy Polska Report: Highway to Electromobility; Innogy: Warsaw, Poland, 2018.

44. Novavis S.A. Monthly report of Novavis S.A. ("Company", "Issuer") for January 2018; Novavis S.A.: Warszawa, Poland, 2018.

45. The World Bank. Netherlands. 2018. Available online: https://data.worldbank.org/country/netherlands (accessed on 15 April 2018).

46. The World Bank. Poland. 2018. Available online: https://data.worldbank.org/country/poland (accessed on 15 April 2018).

47. United Nations. World Urbanization Prospects; United Nations: New York, NY, USA, 2014.

48. Samochody w Pełni Elektryczne (BEV). Available online: http://elektromobilni.pl/bev (accessed on 11 April 2018).

49. Efektywność Energetyczna aut: Samochody Elektryczne-73 Procent, Wodorowe-22 Procent, Spalinowe-13 Procent. Available online: http://elektrowoz.pl/transport/efektywnosc-energetyczna-aut-samochodyelektryczne-73-procent-wodorowe-22-procent-spalinowe-13-procent/ (accessed on 9 November 2018).

50. Nowy Nissan Leaf. Available online: https://www.nissan.pl/pojazdy/nowe-pojazdy/leaf/zasiegladowania.html (accessed on 8 May 2018).

51. Tomtom Trafic Index. Available online: https://www.tomtom.com/en_gb/trafficindex/list?citySize=ALL\& continent=EU\&country=ALL (accessed on 8 May 2018).

52. ACEA. New Passenger Car Registration by Alternative Fuel Type in the Europeanunion; ACEA: Bruksela, Belgium, 2018.

53. Marché du Véhicule Électrique et Hybride. Available online: http:/ / www.avere-france.org/Site/Article/ ?article_id=7287 (accessed on 16 April 2018).

54. Pressemitteilung Nr 08/2018-Fahrzeugzulassungen im März 2018. Available online: https:/ / www.kba.de/ DE/Service/Nachrichten/2018/PM/PM_Nr_08_2018_Fahrzeugzulassungen_03_2018.html (accessed on 13 April 2018).

55. Bilsalget i Mars. Available online: http://www.ofvas.no/bilsalget-i-mars/category767.html (accessed on 26 April 2018).

56. Kałkowska, J.; Pawłowski, E.; Trzcielińska, J.; Trzcieliński, S.; Włodarkiewicz-Klimek, H. Zarzadzanie Strategiczne. Metody Analizy Strategicznej z Przykładami; Wyd. Politechniki Poznańskiej: Poznań, Poland, 2010.

57. Wielicka, K. Analiza strategiczna samodzielnego publicznego zakładu opieki zdrowotnej dla potrzeb jego restrukturyzacji. Studium przypadku. Zesz. Nauk. Org. Zarz. Polit. Ślas. 2012, 60, 377-396.

58. Szydelko, L.; Rubik, J. Enterprise Environment Analysis-Methods in Use and Development Trends. MMR 2016, 21, 215-223. [CrossRef]

59. Gierszewska, G.; Romanowska, M. Analiza Strategiczna Przedsiębiorstwa; Polskie Wydawnictwo Ekonomiczne: Warsaw, Poland, 2017.

60. Golisz, E. Historia, stan aktualny i perspektywy gorzelni rolniczych w Polsce. PFiOW 2013, 57, $23-25$.

61. Antczak, A.; Borowski, P.; Dubowik, M.; Gawron, J.; Golisz, E.; Hebda, M.; Karpiński, S.; Kucner, M.; Kupczyk, A.; Mączyńska, J.; et al. Results of Selected Research Tasks in Project Woodtech; Oficyna Wydawniczo-Poligraficzna Adam: Warsaw, Poland, 2016. 
62. Sikora, M.; Stasiak-Panek, J.; Kupczyk, A. Aktualny stan i atrakcyjność sektorów biopaliw w Polsce. PFiOW 2016, 60, 25-27. [CrossRef]

63. Sunarti, T.C.; Meryandini, A.; Sofiyanto, M.; Richana, N. Saccharification of corncob using cellulolytic bacteria for bioethanol production. Biotropia 2010, 17, 105-114.

64. Sidiras, D. Simulation of acid hydrolysis of lignocellulosic residues to fermentable sugars for bioethanol production. AIP Conf. Proc. 2012, 1504, 1091. [CrossRef]

65. Meena, S.; Navatha, S.; Prabhavathi Devi, B.; Prasad, R.; Pandey, A.; Sukumaran, R.K. Evaluation of Amberlyst15 for hydrolysis of alkali pretreated rice straw and fermentation to ethanol. Biochem. Eng. J. 2015, 102, 49-53. [CrossRef]

66. Meighan, B.N.; Lima, D.; Cardoso, W.J.; Baêta, B.; Adarme, O.F.H.; Santucci, B.S.; Gurgel, L.V.A. Two-stage fractionation of sugarcane bagasse by autohydrolysis and glycerol organosolv delignification in a lignocellulosic biorefinery concept. Ind. Crops Prod. 2017, 108, 431-441. [CrossRef]

67. Thuy Duong, N.T.; Praveen, P.; Loh, K.-C. Zymomonas mobilis Immobilization in Polymeric Membranes for Improved Resistance to Lignocellulose-Derived Inhibitors in Bioethanol Fermentation. Biochem. Eng. J. 2018, 140, 29-37. [CrossRef]

68. Xylia, M.; Silveira, S. The role of charging technologies in upscaling the use of electric buses in public transport: Experiences from demonstration projects. Transp. Res. Part A 2018, 118, 399-415. [CrossRef]

69. De Souza, L.; Lora, E.; Palacio, J.; Rocha, M.; Renó, M.; Venturini, O. Comparative environmental life cycle assessment of conventional vehicles with different fuel options, plug-in hybrid and electric vehicles for a sustainable transportation system in Brazil. J. Clean. Prod. 2018. [CrossRef]

70. Ferreira de Lara, F.; Marx, R. Comparative positioning between Brazilian subsidiaries and European matrices on Electromobility and carsharing technologies. Res. Transp. Bus. Manag. 2018, in press.

71. Joller, L.; Varblane, U. Learning from an electromobility living lab: Experiences from the Estonian ELMO programme. Case Stud. Transp. Policy 2016, 4, 57-67. [CrossRef]

72. Wolfgang Kuhn, P.E. Methodolody for planning multi-functional transport corridors taking into consideration the special requirements of electromobility. Transp. Res. Procedia 2017, 25, 3446-3458. [CrossRef]

73. May, N. Local environmental impact assessment as decision support for the introduction of electromobility in urban public transport systems. Transp. Res. Part D Transp. Environ. 2018, 64, 192-203. [CrossRef]

74. REN21. Renewables 2018 Global Status Report; REN21: Paris, France, 2018.

75. Melander, L.; Dubois, A.; Hedvall, K.; Lind, F. Future goods transport in Sweden 2050: Using a Delphi-based scenario analysis. Technol. Forecast. Soc. Chang. 2018, in press. [CrossRef]

76. Zawieska, J.; Pieriegud, J. Smart city as a tool for sustainable mobility and transport decarbonisation. Transp. Policy 2018, 63, 39-50. [CrossRef]

77. Morganti, E.; Browne, M. Technical and operational obstacles to the adoption of electric vans in France and the UK: An operator perspective. Transp. Policy 2018, 63, 90-97. [CrossRef]

78. Hooftman, N.; Messagie, M.; Van Mierlo, J.; Coosemans, T. A review of the European passenger car regulations-Real driving emissions vs local air quality. Renew. Sustain. Energy Rev. 2018, 86, 1-21. [CrossRef]

79. Sprei, F. Disrupting mobility. Energy Res. Soc. Sci. 2018, 37, 238-242. [CrossRef]

80. Cansino, J.M.; Yñiguez, R. Promoting electro mobility in Spain. Public measures and main data (2007-2012). Transp. Res. Part D Transp. Environ. 2018, 59, 325-345. [CrossRef]

81. Izdebski, W.; Skudlarski, J.; Zając, S. Wykorzystanie surowców pochodzenia rolniczego do produkcji biopaliw transportowych w Polsce. RN SERiA 2014, 16, 93-97.

82. Piwowar, A. Produkcja biokomponentów i biopaliw ciekłych w Polsce-tendencje rozwoju i regionalne zróżnicowanie. RN SERiA 2015, 17, 196-200.

83. Tucki, K.; Kupczyk, A. Influence of the manufacturing technology process on properties of rapeseed oil. In Proceedings of the International Scientific Conference: Rural Development, Kaunas, Lituania, 23-24 November 2017; Volume 1, pp. 481-484. [CrossRef]

84. Langbroek, J.; Franklin, J.P.; Susilo, Y.O. A stated adaptation instrument for studying travel patterns after electric vehicle adoption. Transp. Res. Procedia 2018, 32, 464-473. [CrossRef]

85. Biresselioglu, M.E.; Kaplan, M.D.; Yilmaz, A.B. Electric mobility in Europe: A comprehensive review of motivators and barriers in decision making processes. Transp. Res. Part A Policy Pract. 2018, 109, 1-13. [CrossRef] 
86. Rečka, L.; Ščasný, M. Brown coal and nuclear energy deployment: Effects on fuel-mix, carbon targets, and external costs in the Czech Republic up to 2050. Fuel 2018, 216, 494-502. [CrossRef]

87. Kaur, H.; Garg, P. Urban sustainability assessment tools: A review. J. Clean. Prod. 2019, 210, 146-158. [CrossRef]

88. Safarzyńska, K.; Van den Bergh, C.J.M. A higher rebound effect under bounded rationality: Interactions between car mobility and electricity generation. Energy Econ. 2018, 74, 179-196. [CrossRef]

89. Simsekoglu, O. Socio-demographic characteristics, psychological factors and knowledge related to electric car use: A comparison between electric and conventional car drivers. Transp. Policy 2018, 72, 180-186. [CrossRef]

90. Danielis, R.; Giansoldati, M.; Rotaris, L. A probabilistic total cost of ownership model to evaluate the current and future prospects of electric cars uptake in Italy. Energy Policy 2018, 119, 268-281. [CrossRef]

91. Connolly, D. Economic viability of electric roads compared to oil and batteries for all forms of road transport. Energy Strategy Rev. 2017, 18, 235-249. [CrossRef]

92. Hoffmann, C.; Abraham, C.; Skippon, S.M.; White, M.P. Cognitive construction of travel modes among high-mileage car users and non-car users-A Repertory Grid analysis. Transp. Res. Part Policy Pract. 2018, 118, 216-233. [CrossRef]

93. Li, M.; Xu, J.; Xie, H.; Wang, Y. Transport biofuels technological paradigm based conversion approaches towards a bio-electric energy framework. Energy Convers. Manag. 2018, 172, 554-566. [CrossRef]

94. Kannan, R.; Hirschberg, S. Interplay between electricity and transport sectors-Integrating the Swiss car fleet and electricity system. Transp. Res. Part A Policy Pract. 2016, 94, 514-531. [CrossRef]

95. López-Lambas, M.E.; Monzón, A.; Pieren, G. Analysis of using electric car for urban mobility, perceived satisfaction among university users. Transp. Res. Procedia 2017, 27, 524-530. [CrossRef]

96. Woods, R.; Masthoff, J. A comparison of car driving, public transport and cycling experiences in three European cities. Transp. Res. Part A Policy Pract. 2017, 103, 211-222. [CrossRef]

97. Profillidis, V.A.; Botzoris, G.N. Chapter 2: Evolution and Trends of Transport Demand. In Modeling of Transport Demand; Profillidis, V.A., Botzoris, G.N., Eds.; Elsevier: Cambridge, MA, USA, 2019; pp. 47-87, ISBN 9780128115138.

98. Ruiz, V.; Pfrang, A.; Kriston, A.; Omar, N.; Van den Bossche, P.; Boon-Brett, L. A review of international abuse testing standards and regulations for lithium ion batteries in electric and hybrid electric vehicles. Renew. Sustain. Energy Rev. 2018, 81, 1427-1452. [CrossRef]

99. Gallet, M.; Massier, T.; Hamacher, T. Estimation of the energy demand of electric buses based on real-world data for large-scale public transport networks. Appl. Energy 2018, 230, 344-356. [CrossRef]

100. Morton, C.; Anable, J.; Yeboah, G.; Cottrill, C. The spatial pattern of demand in the early market for electric vehicles: Evidence from the United Kingdom. J. Transp. Geogr. 2018, 72, 119-130. [CrossRef]

101. Kershaw, J.; Berkeley, N.; Jarvis, D.; Begley, J. A feeling for change: Exploring the lived and unlived experiences of drivers to inform a transition to an electric automobility. Transp. Res. Part D Transp. Environ. 2018, 65, 674-686. [CrossRef]

102. Wójcik, M.; Pawłowska, B.; Stachowicz, F. Przegląd technologii recyklingu zużytych akumulatorów litowo-jonowych. Zesz. Nauk. Polit. Rzesz. 2017, 89, 107-120.

(C) 2019 by the authors. Licensee MDPI, Basel, Switzerland. This article is an open access article distributed under the terms and conditions of the Creative Commons Attribution (CC BY) license (http://creativecommons.org/licenses/by/4.0/). 